\title{
HLA-Bw6 Antigen
}

National Cancer Institute

\section{Source}

National Cancer Institute. HLA-Bw6 Antigen. NCI Thesaurus. Code C71270.

HLA-BW6 antigen is the public epitope associated with the sequence of amino acid residues at positions 77-83 in the alpha one domain of the HLA class I heavy chain encoded by various alleles of the human HLA-B gene. 